\title{
REGULATORY APPROACHES TO FACEBOOK AND OTHER SOCIAL MEDIA PLATFORMS: TOWARDS PLATFORMS DESIGN ACCOUNTABILITY*
}

by

JÁN MAZÚR ${ }^{* *}$, MÁRIA T. PATAKYOVÁ****

The paper represents a contribution to the ongoing discussion on regulating social media platforms (SMP) and especially Facebook, mostly fueled by a recent series of scandals such as Cambridge Analytica, which highlighted the recognized problem of Facebook's lack of accountability. In response to the scandal, which coincided with long-expected wide-scale implementation of the EU's GDPR, Facebook introduced a series of measures on its platform, such as improved traceability of advertisers, or greater power over one's own data. Besides, Facebook was put under scrutiny of competition law authorities, mainly the German Bundeskartellamt. Taking into consideration all the regulatory approaches, the question remains whether sufficiently effective design for holding the SMPS accountable has been established or not. In the paper, we first outline the accountability issues SMPs currently face, namely the data handling and privacy issue, the platforms' impact on political processes, or related monopolistic positioning. We ascertain that common denominator of these issues is the platforms' design, which is created to achieve business objectives, while imposing substantial negative externalities on the society. Alongside, we review the platforms' reactions, i.e. the self-regulatory measures adopted by the platforms in 2017-2018. We also specifically focus on the evaluation of the competition law

\footnotetext{
This contribution is the result of the project implementation APVV-16-0553 Metamorphoses and innovations of the corporations' concept under conditions of globalisation (Premeny a inovácie konceptu kapitálových spoločností v podmienkach globalizácie).

* jan.mazur@flaw.uniba.sk, Assistant Professor, Department of Financial Law, Faculty of Law, Comenius University in Bratislava, Slovak Republic.

*** maria.patakyova2@flaw.uniba.sk, Assistant Professor, Institute of European Law, Faculty of Law, Comenius University in Bratislava, Slovak Republic.
} 
as one instrument of regulating certain aspects of the platforms, especially in light of the recent German Bundeskartellamt decision on Facebook. We claim that most of the measures and current instruments, although improving the lack of accountability, fall short of addressing the core issue of Facebook's statusabsence of scrutiny over the platform's design.

\section{KEY WORDS}

Abuse of Dominant Position, Accountability, Competition Law, Data Protection, Facebook, Platform's Design, Self-regulation, Social Media Platforms

\section{INTRODUCTION}

Facebook and other social media platforms (SMP) ventured far from being generally understood as actors for the common good. ${ }^{1}$ There were numerous cases of abuses of the platforms, by third parties or platforms themselves, accidental or deliberate. Notorious influencing of elections in USA, or France, based on fake profiles and bots, creation and amplification of fake content, led to massive investigation and political uproar. $^{2}$ Such events are a reason for great concern, particularly to established democracies as they appear to be more susceptible to fake news techniques. ${ }^{3}$ The mishandling of users' data by Facebook, especially in relation to third parties such as Cambridge Analytica, is alarming. ${ }^{4}$ SMPs also became means of promotion of religious and racial hatred against

1 Tufekci, Z. (2018) How social media took us from Tahrir Square to Donald Trump. MIT Technology Review. [online] Available from: http://www.technologyreview.com/s/611806/ how-social-media-took-us-from-tahrir-square-to-donald-trump/ [Accessed 15 March 2019].

2 Guess, A., Nagler, J. and Tucker, J. (2019) Less than you think: Prevalence and predictors of fake news dissemination on Facebook. Science Advances, 5 (1). [online] doi: 10.1126/sciadv. aau4586 [Accessed 15 March 2019]; Ferrara, E. (2017) Disinformation and social bot operations in the run up to the 2017 French presidential election. First Monday, 22 (8). [online] doi: 10.5210/fm.v22i8.8005 [Accessed 15 March 2019]; Allcott, H. and Gentzkow, M. (2017) Social Media and Fake News in the 2016 Election. Journal of Economic Perspectives, 31 (2), pp. 211-236. [online] doi: 10.1257/jep.31.2.211 [Accessed 15 March 2019]; Hansen, I. and Lim, D. J. (2018) Doxing democracy: influencing elections via cyber voter interference. Contemporary Politics, 25 (2), pp. 150-171. [online] doi: 10.1080/13569775.2018.1493629 [Accessed 15 March 2019]; see the US Senate Judiciary Committee's report in Senate Judiciary Committee. (2017) Extremist content and Russian disinformation online: Working with tech to find solutions. [online] Available from: www.judiciary.senate.gov/meetings/extremistcontent-and-russian-disinformation-online-working-with-tech-to-find-solutions [Accessed 15 March 2019].

3 Farrell, H. J. and Schneier, B. (2018) Common-Knowledge Attacks on Democracy. SSRN Electronic Journal. [online] doi: 10.2139/ssrn.3273111 [Accessed 15 March 2019].

4 Isaak, J. and Hanna, M. J. (2018) User Data Privacy: Facebook, Cambridge Analytica, and Privacy Protection. Computer, 51 (8), pp. 56-59. [online] doi: 10.1109/mc.2018.3191268 [Accessed 15 March 2019]; Bartlett, J. (2018) Big data is watching you - and it wants your vote. The Spectator, 24 March. [online] Available from: https://www.spectator.co.uk/2018/03/ big-data-is-watching-you-and-it-wants-your-vote/ [Accessed 15 March 2019]. 
certain communities (e.g. the case of Rohingya, mob murders in India). ${ }^{5}$ To sum it up, the platforms have become political market places with wide social implications, which necessarily leads to the question of accountability of the platforms. ${ }^{6}$

The paper focuses on the issue of accountability while it examines the regulatory approaches towards the platforms. In particular, the paper asks, first, what are the factors suggesting the lack of accountability of SMPs; second, whether SMPs may be efficiently regulated by currently available regulatory mechanisms, in particular by competition law after the Bundeskartellalmt Facebook decision; and third, what the underlying problems of regulating SMPs are.

In the first part, we review accountability deficits, selected according to their gravity and representativeness in the media, and reflect on the current regulatory regimes. We also briefly review self-regulatory measures applied by the platforms. In the second part of the paper, we specifically focus on the recent development in the competition law in relation to SMPs. Finally, we discuss prospective regulatory measures.

\section{ACCOUNTABILITY DEFICITS OF SMPS}

One of the core issues of platforms lies in the legal understanding of platforms: what are SMPs from legal point of view? SMPs have long been recognized as internet service providers (ISP), who are generally not responsible for the content published on their services by the users. ${ }^{7}$ Unlike ISPs, traditional media are responsible and liable for the published content, as they are gatekeepers for third party content, and they produce content on their own. Understanding SMPs as traditional media requires making them responsible for the users' content, which is not feasible and could be arguably disproportionate as to the objectives of such measure. ${ }^{8}$ But while SMPs do not produce content, their algorithms curate the content on behalf

5 Goel, V. et al. (2018) How WhatsApp Leads Mobs to Murder in India. The New York Times, 18 July. [online] Available from: http://www.nytimes.com/interactive/2018/07/18/technology /whatsapp-india-killings.html [Accessed 15 March 2019]; Müller, K. and Schwarz, C. (2017) Fanning the Flames of Hate: Social Media and Hate Crime. SSRN Electronic Journal. [online] doi: 10.2139/ssrn.3082972 [Accessed 15 March 2019].

6 Ceron, A. (2018) Social Media and Political Accountability Bridging the Gap between Citizens and Politicians. Cham, Switzerland: Palgrave Macmillan, p. 205.

7 Jeweler, M. G. (2008) The Communications Decency Act of 1996: Why $§ 230$ is Outdated and Publisher Liability for Defamation Should be Reinstated Against Internet Service Providers. Pittsburgh Journal of Technology Law and Policy, 8. [online] doi: 10.5195/tlp.2008.40 [Accessed 15 March 2019]. 
of users, for instance in prioritization and personalization. Such curation is not unlike curation in traditional media, although done automatically and with high degree of personalization. ${ }^{9}$

Understanding SMPs as a form of traditional media does not capture the nature of SMPs to their full extent. From a socio-political perspective, SMPs seem to effectively serve as online public fora. Some recent court decisions underline the political nature and importance of such public fora for free speech. For instance, in recent Knight First Amendment Institute v. Trump (2018), the court held that the President's Twitter account effectively serves as a public forum and that

"the blocking of the plaintiffs based on their political speech constitutes viewpoint discrimination that violates the First Amendment". ${ }^{10}$

Commenting and disagreeing with online statuses and tweets constitutes protected speech with protected access. ${ }^{11}$ A similar decision was reached by the US District Court in Virginia, upheld by the 4th US Circuit Court of Appeals in 2019, when the court held that a Facebook page is deliberately designed to be a "public forum", which if used by the politicians, represents a constitutionally protected space. If a politician designates such space as a place or channel of communication for use by the public, notwithstanding that it is placed on a privately-operated platform, it is "more than sufficient to create a forum for speech". ${ }^{12}$

8 Although the platforms have long moderated the content and their users, in many instances they did so based on unclear and changing private rules, which cannot be influenced by the users, and with limited recourse. SMPs create a unique type of cyberspaces with continuous monitoring of economically, socially and politically relevant behavior, which brings in well-recognized identity dilemma; anonymity breeds abuses of free speech, cyberbullying, and trolling, yet disclosure brings profiling and privacy risks.

9 Lazer, D. (2015) The rise of the social algorithm. Science, 348 (6239), pp. 1090-1091. [online] doi: 10.1126/science.aab1422 [Accessed 15 March 2019].

${ }_{10}$ Calvert, C. (2018) Federal judge rules Trump's Twitter account is a public forum. The Conversation, 24 May. [online] Available from: http://theconversation.com/federal-judgerules-trumps-twitter-account-is-a-public-forum-97159 [Accessed 15 March 2019].

11 The ruling (2nd instance decision pending) has numerous implications. First, it implies that the existence of myriads of public fora, i.e. the walls, feeds and posts of individual politicians and publicly active persons, who are ascribed responsibility for maintaining the integrity of these fora. The content responsibility of platforms remains limited. Second, a question of restricting other people from access to the public fora based on different grounds, such as they are banned from SMPs on different grounds, based on private regulation arises. Third, it does not deal specifically with cross-jurisdictional issues and related options of recourse. The decision does not represent a regulation of SMPs but rather public figures and public bodies active on SMPs.

12 Brian C. Davison v. Loudon County Board of Supervisors et al. (2017) 1:16cv932 (JCC/IDD). 


\subsection{INCREASE OF SELF-REGULATORY EFFORTS}

Once SMPs are understood as media or as public fora, admittedly, they should maintain a degree of control of what is written thereon. Although for a long time SMPs were hesitant as to the regulation of users' content, it has become clear that some users' behavior is considered undesirable by the general public, or as Facebook puts it, there is "bad content" produced by "bad actors". ${ }^{13}$ While it may be clear in most instances what represents a bad content and who the bad actor is, there should certainly be a wider policy discussion on this, involving public sector, given the importance of these fora for the public discourse. As a part of the efforts to regulate bad content, Facebook started to publish regular reports on its conduct. However, SMPs need well-staffed teams of content moderators - native speakers in order to understand local contexts, irony, sarcasm, in prevention of harassing reports. ${ }^{14}$

The debate over content moderation also leads to the question of independent review of SMPs' decisions. Facebook itself proposed setting up of an independent oversight group to review content moderation appeals and adjudicate them. ${ }^{15}$ The logic of such intervention, as Facebook claims, is to prevent the concentration of too much decision-making within Facebook teams and to achieve platform's accountability, oversight and assurance

"that decisions are made in the best interest of the online community and not for commercial reasons." 16

The oversight group should be a platform's analog to the US Supreme Court, with the ability to create case law and to adapt the decision making to local

13 Facebook claims to take down more of "bad" content than ever, also proactively (Q3 2018 $15,4 \mathrm{M})$. Take down of fake accounts $( \pm 750-800 \mathrm{M} / \mathrm{Q})$ - mostly used as spamming accounts (still about $3-4 \%$ of active users are fake accounts). Facebook Newsroom. (2018) How Are We Doing at Enforcing Our Community Standards?. [press release] 15 November. Available from: http://newsroom.fb.com/news/2018/11/enforcing-our-community-standards-2/ [Accessed 15 March 2019].

14 As was publicized widely, there appears to be very limited time dedication of these content moderators as these positions seem to be highly understaffed and underpaid. See: Newton, C. (2019) The secret lives of Facebook moderators in America. The Verge, 25 February. [online] Available from: https://www.theverge.com/2019/2/25/18229714/cognizant-facebook-contentmoderator-interviews-trauma-working-conditions-arizona [Accessed 15 March 2019].

15 Zuckerberg, M. (2018) A Blueprint for Content Governance and Enforcement.[press release] 15 November. Available from: https://www.facebook.com/notes/mark-zuckerberg/a-blue print-for-content-governance-and-enforcement/10156443129621634/ [Accessed 15 March 2019].

16 Ibid. 
freedom of speech norms and laws. Still there are multiple unanswered questions regarding the oversight group. ${ }^{17}$

On top of individual abuses of platform design, SMPs have been abused by various more or less organized cyber actors, including state and non-state actors. These abuses are grave and have a potential of influencing democratic processes by polarizing societies, strengthening distrust and shifting political discourse. Some platforms, such as Facebook, attempted to address some of these threats. Facebook started to work with government and law enforcement agencies (FBI, Department of Homeland Security, etc.), cybersecurity researchers and other tech companies. It claims to coordinate and exchange real-time updates on emerging threats and disinformation campaigns with agencies and think tanks. ${ }^{18}$ Also, Facebook launched cross-sectoral elections war rooms, 1st time in September 2018, where subject-matter experts from across the company gather to address potential problems and respond in real time.

The bad actors Facebook mentions exploit the platforms' design oriented on pursuing the platforms' business interests, including such features as tendency of sensational news and spam to spread easily (e.g. clickbaits, viral spam, fake news). In recent self-regulatory action, Facebook started to change algorithms to mitigate the negative effects of these sensational news and spam. ${ }^{19}$ Similarly, WhatsApp changed its design to limit the number of people one can forward a message to tackle spreading of fake and dangerous news. ${ }^{20}$ The fundamental logic of these actions is to disrupt economic incentives of bad actors on SMPs through design changes of the service. Facebook claims that its algorithms will distribute needlessly provocative posts less and less, preventing them from seeing a spike in engagement. Such action is mostly related to the so-called borderline

17 For instance, it is unclear how the selection of members of the group would go about, how the independence would be secured, what rules the group would follow, or how the group would select the cases from thousands of applicants.

18 Facebook Newsroom. (2018) Fighting Election Interference in Real Time. [press release] 18 October. Available from: https://newsroom.fb.com/news/2018/10/war-room/ [Accessed 15 March 2019].

19 Zuckerberg, M. (2018) A Blueprint for Content Governance and Enforcement. [press release] 15 November. Available from: https://www.facebook.com/notes/mark-zuckerberg/a-blue print-for-content-governance-and-enforcement/10156443129621634/ [Accessed 15 March 2019].

20 Wagner, K. (2018) WhatsApp will drastically limit forwarding to stop the spread fake news, following violence in India and Myanmar. Recode, 19 July. Available from: https://www.recode.net/2018/7/19/17594156/whatsapp-limit-forwarding-fake-newsviolence-india-myanmar [Accessed 15 March 2019]. 
content, which is not necessarily prohibited by the Facebook "Community Rules" but are nevertheless abusive, misguiding or otherwise problematic.

Some shortcomings of SMPs are related to information asymmetries; a theory goes that as people do not know who spreads certain news, they cannot evaluate the trustworthiness of the originator of the message. This in turn leads to a situation when people share controversial news without realizing that not all the news originators in the cyberspace are equally trustworthy or openly claim their interests. Providing people with more information on the page owners should therefore increase the probability that some users would double-check the trustworthiness before reposting certain messages. For instance, Facebook started to provide additional previously undisclosed information on Facebook pages, such as changes to the page name, in order to assess their credibility, genuineness and motives. ${ }^{21}$ Similarly, Facebook introduced a tool that provided, in some countries, related, fact-checked sources next to disputed ones. ${ }^{22}$ Some SMPs also introduced political advertisers verification in order to increase political ads transparency, in the wake of the US Honest Ads Act..$^{23}$ There is a tendency to strengthen the identity verification of influential actors and accounts. $^{24}$

\subsection{NEED FOR OTHER TYPES OF REGULATION}

All the self-regulatory efforts mentioned in the previous section are laudable, however, we believe that they do not address the problem properly. First, many of these efforts are self-initiated. Although SMPs have been under public pressure recently, there is hardly a legal basis for Facebook to tackle the information asymmetry, or for WhatsApp to mitigate the spread of fake news. There is a risk of detriment to the core values of any SMP in the future, which leaves these public fora and public

${ }^{21}$ Cox, J. (2018) Facebook Is Testing a Feature to Tell You If That DM Came from Russia. VICE, 10 July. [online] Available from: https://motherboard.vice.com/en_us/article/ne5wgw/ facebook-testing-feature-direct-message-from-russia? [Accessed 15 March 2019].

22 Silverman, C. (2017) Facebook Is Getting Rid Of Its Fact-Checking Label And Replacing It With This. BuzzFeed News, 20 December. [online] Available from: https://www.buzzfeed news.com/article/craigsilverman/facebook-is-getting-rid-of-its-fact-checking-label-and\#.vq1 28VVB1 [Accessed 15 March 2019].

${ }^{23}$ Zuckerberg, M. (2018) Note. [press release] 6 April. Available from: https://www.facebook. com/zuck/posts/10104784125525891 [Accessed 15 March 2019].

24 Stewart, E. (2018) Zuckerberg and Facebook are in trouble. Here's what the government might do about it. Vox, 10 April. [online] Available from: https://www.vox.com/policy-andpolitics/2018/4/10/17208322/facebook-mark-zuckerberg-congress-testimony-regulation

[Accessed 15 March 2019]. 
discourse vulnerable to abuses by the platforms themselves. This brings us to second issue - the platforms' design. Any oversight group would not address the core problem of the platform's design; the community will have to adopt the standards and norms as provided by SMPs, and not originate them. The oversight group would be merely an interpreter of rules, and perhaps a limited creator of norms, in terms of case law. Therefore, the implementation of oversight group would have only limited impact on the core problem of the platforms' design.

\section{COMPETITION LAW AS A PANACEA?}

Although the self-regulation should not be underestimated, it follows from the above that there should be a regulator separated from the SMPs. Self-regulation may serve as the first layer of regulation, similarly as a supervisory body of a corporation serves as an internal mechanism of control. However, existence of such supervisory body does not mean that there should not be external controllers, such as auditors, tax authorities, competition authorities, etc. Thus, what external regulatory mechanisms relevant for the issues described above can we identify?

\subsection{THE THREE REGULATORY MECHANISMS}

From among the prospective regulatory mechanisms we discuss three applicable mechanisms on SMPs, all targeting various aspects of the platforms. ${ }^{25}$ The first one is the regulation through personal data protection. SMPs own considerable amount of data whereas much of it may fall within the definition of personal data pursuant to Article 4(1) of GDPR. ${ }^{26}$ Given the large applicability of GDPR, possibility to impose high fines and pan-European character of the regulation, GDPR is of vital importance for regulation of SMPs. However, GDPR is of no use if a consent of data subjects is given ${ }^{27}$, or if data processed by SMPs are no longer personal data. The latter is often the case when big data are at stake, i.e.

25 See, for instance: Kerber, W. (2016) Digital markets, data, and privacy: competition law, consumer law and data protection. Journal of Intellectual Property Law E Practice, 11 (11), pp. 856-866; Botta, M. and Wiedemann, K. (2018) EU Competition Law Enforcement vis-à-vis Exploitative Conducts in the Data Economy Exploring the Terra Incognita. Max Planck Institute for Innovation and Competition Research Paper, 18-08, p. 23 et seq. [online] Available from: https://ssrn.com/abstract=3184119 [Accessed 4 March 2019].

${ }_{26}$ Regulation (EU) 2016/679 of the European Parliament and of the Council of 27 April 2016 on the protection of natural persons with regard to the processing of personal data and on the free movement of such data, and repealing Directive 95/46/EC (General Data Protection Regulation). Official Journal of the European Union (2016/L-119/1) 4 May. 


\section{"the collection and processing of large quantities of data through sophisticated methods (e.g. advanced processing through algorithms)."28}

The second regulatory mechanism is related to consumer protection, which is part of legal orders of all EU Member States. Consumers are defined as persons who do not act within their professional capacity, hence are more vulnerable in contractual relations. Their lack of professional knowledge is compensated by cogent legal norms which impose duties on businesses as the other parties of contractual relationships. ${ }^{29}$ One of the aims of these cogent legal norms is to protect consumers from unfair contractual terms. In certain areas of law, protection from unfair contractual terms is given to non-consumers as well. ${ }^{30}$ Although these special areas of law are rarely applicable to the SMPs, consumer protection law falls within the scope of our analysis, since users of SMPs are, as a rule, consumers. If a contractual term causes a severe inequity between a consumer and a business to the detriment of a consumer, such unfair contractual term may be invalid even though the consumer has agreed to it. ${ }^{31}$ Therefore, such unfair terms may cover undisclosed harvesting of consumer's data, vague use of data, non-user-friendly terms and conditions. ${ }^{32}$ Although part of these issues may be solved by personal data protection law, consumer protection may go, at least in theory, further, as it is not limited to acquiring and handling of personal data. However,

27 Article 7 GDPR. To the notion of consent, see, for example: Botta, M. and Wiedemann, K. (2018) EU Competition Law Enforcement vis-vis-à-visà-vis Exploitative Conducts in the Data Economy Exploring the Terra Incognita. Max Planck Institute for Innovation and Competition Research Paper. 18-08, p. 23 et seq. [online] Available from: https://ssrn.com/ abstract=3184119 [Accessed 4 March 2019]; Hintze, M. (2018) Viewing the GDPR through a De-Identification Lens: A Tool for Compliance, Clarification, and Consistency. International Data Protection Law, 8 (1), pp. 86-101.

28 Davilla, M. (2017) Is Big Data a Different Kind of Animal? The Treatment of Big Data Under the EU Competition Rules. Journal of European Competition Law \& Practice, 8 (6), p. 370. For another definition of big data, see: Stucke, M. E. and Alan, G. P. (2016) Big Data and Competition Policy. 1st ed. Oxford: Oxford University Press, p. 15 et seq.

29 This follows, for instance, from Recitals 17, 34, 39 etc. of Directive 2011/83/EU of the European Parliament and of the Council of 25 October 2011 on consumer rights, amending Council Directive 93/13/EEC and Directive 1999/44/EC of the European Parliament and of the Council and repealing Council Directive 85/577/EEC and Directive 97/7/EC of the European Parliament and of the Council. Official Journal of the European Union (2011/L-304/64) 22 November.

30 See, for instance, sections 369a et seq. of Commercial Code: Obchodný zákonník 2019. SI 1991/513. Slovak Republic. In Slovak; Act on Unfair Conditions in Commercial Relations with Food as the Object: Zákon o neprimeraných podmienkach vobchodných vztahoch, ktorých predmetom sú potraviny 2013. SI 2012/369. Slovak Republic. In Slovak.

31 Section 53 of Civil Code: Občiansky zákonník 2019. SI 1964/40. Slovak Republic. In Slovak.

32 Kerber, W. (2016) Digital markets, data, and privacy: competition law, consumer law and data protection. Journal of Intellectual Property Law \& Practice, 11 (11), pp. 861-863. 
the enforcement mechanism of consumer law seems to be weaker than the enforcement of GDPR. ${ }^{33}$

The last regulatory mechanism which is lively discussed among scholars is competition law. Together with ex ante control of mergers, which may prevent creation of too strong undertakings, competition law may tackle abuses of dominant position as well as agreements restricting competition. The supranational enforcement mechanism and the detergence effect of substantial fines which may be imposed by competition authorities make scholars wonder whether this might be the most suitable regulatory mechanisms for SMPs. We will discuss the adequacy of such thoughts in more detail.

\subsection{ABUSE OF DOMINANT POSITION OF SMPS}

In general, legal theory distinguishes between exclusionary abusive practices and exploitative abusive practices. The former aims to preventing the development of competition by a dominant undertaking, the latter is mainly concerned with charging of unfair prices by a dominant undertaking. ${ }^{34}$

Regarding exclusionary practices, it is questionable whether the position of certain SMPs, mainly Facebook, qua persons with access to great amount of data, puts them in position of owners of an essential facility. ${ }^{35}$ If this was the case, competitors of Facebook could ask Facebook to give access to its data by arguing that otherwise they would be excluded from competition. However, this would hardly work in practice. ${ }^{36}$ Moreover, it would mean that even more persons would have access to data and could use them in similar manner as Facebook can. In other words, even if the competition

33 To this end, see, for instance, Patakyová, M. and Mazúr, J. (2018) Facebook - Global Issue without (Existing) Solution? In: Tomas Kliestik (ed.). Globalization and Its Socio-Economic Consequences 18th International Scientific Conference, Proceedings, (Part V. - Digital Single Market). Rajecké Teplice, 10-11 October. Žilina: University of Žilina.

34 Whish, R. and Bailey, D. (2012) Competition Law. 7th ed. Oxford University Press, p. 201; Jones, A. and Sufrin, B. (2016) EU Competition Law. Text, Cases and Materials. 6th ed. Oxford: Oxford University Press, p. 352.

35 Botta, M. and Wiedemann, K. (2018) EU Competition Law Enforcement vis-à-vis Exploitative Conducts in the Data Economy Exploring the Terra Incognita. SSRN Electronic Journal, p. 46 et seq. doi: 10.2139/ssrn.3184119 [Accessed 15 March 2019].

36 Davilla, M. (2017) Is Big Data a Different Kind of Animal? The Treatment of Big Data Under the EU Competition Rules. Journal of European Competition Law E Practice, 8 (6), p. 380. [online] doi: 10.1093/jeclap/lpx039 [Accessed 15 March 2019]; Colangelo, G. and Maggiolino, M. (2018) Data Accumulation and the Privacy-Antitrust Interface: Insights from the Facebook Case for the EU and the U.S. SSRN Electronic Journal, p. 43. [online] doi: 10.2139/ssrn.3125490. Available from: https://ssrn.com/abstract $=3125490$ [Accessed 2 March 2019]. 
was better off, the privacy concerns would be aggravated. ${ }^{37}$ This is certainly not what a regulation should stand for. Arguably, the regulation should aim to control the power currently possessed by certain SMPs, namely Facebook, as opposite to spreading the power to virtually all SMPs. Therefore, exploitative practices seem to be better suited for issues related to SMPs.

At the very beginning of any discussion related to exploitative practices it is worth mentioning that competition authorities usually put their hands off this type of abuse, and they have good reasons to do so. Exploitative practices are related to excessive prices for products/services. The idea is that, since an undertaking holds dominant position, it may charge unfair prices for its customers (consumers) and, therefore, exploit them. It is often very difficult to establish the level above which the price for a product/ service is excessive, especially when cost-based analysis cannot be used. This is the case for many intellectual property rights, such as copyrights. ${ }^{38}$

In terms of SMPs, the situation with price for their services is even more complex. On the one hand, SMPs provide space for advertisement. Advertisers pay for this service by money. On the other hand, SMPs provide social networking services to their users. In this case, users pay by their attention and data. ${ }^{39}$ On the latter market, the idea of abuse lies in SMPs selling their social networking services for too high price, i.e. harvesting of too much data ${ }^{40}$ or based on unclear terms or processing them for wrong purposes. However, how can one establish that the price charged for social networking services is too high?

\subsection{GERMAN FACEBOOK CASE}

In March 2016, the German competition authority, Bundeskartellamt, initiated proceedings against Facebook for potential breach of German

${ }^{37}$ Kerber, W. (2016) Digital Markets, Data, and Privacy: Competition Law, Consumer Law, and Data Protection. SSRN Electronic Journal, p. 861. [online] doi: 10.2139/ssrn.2770479 [Accessed 15 March 2019].

38 See for instance: Patakyová, M. (2018) How to Assess the Exploitative Practices of Collecting Societies? European Competition and Regulatory Law Review, 1 (4), pp. 306-319. [online] doi: 10.21552/core/2017/4/6 [Accessed 15 March 2019].

39 Kerber, W. (2016) Digital Markets, Data, and Privacy: Competition Law, Consumer Law, and Data Protection. SSRN Electronic Journal, p. 860. [online] doi: 10.2139/ssrn.2770479 [Accessed 15 March 2019]; Newman, J. M. (2015) Antitrust in Zero-Price Markets: Foundations. University of Pennsylvania Law Review, 164 (1), pp. 149-206; Langhanke, C. and Schmidt-Kessel, M. (2015) Consumer Data as Consideration. Journal of European Consumer and Market Law, 4 (6), pp. 218-223.

40 Colangelo, G. and Maggiolino, M. (2018) Data Accumulation and the Privacy-Antitrust Interface: Insights from the Facebook case for the EU and the U.S. SSRN Electronic Journal, p. 21. [online] Available from: https://ssrn.com/abstract=3125490 [Accessed 2 March 2019]. 
competition rules. $^{41}$ It was clear that Bundeskartellamt would connect infringement of data protection law with abuse of dominant position of Facebook, however, it was not clear how the authority would like to do that. This puzzle was solved recently, as in February 2019, Bundeskartellamt issued decision by which it prohibited Facebook from continuing its practice. $^{42}$ It was held that

"[t]he extent to which Facebook collects, merges and uses data in user accounts constitutes an abuse of a dominant position." 43

It was of crucial importance how Bundeskartellamt would define the relevant market. Eventually, the product market for social networks was chosen as the relevant one. ${ }^{44}$ Facebook is thus considered to hold dominant position on this market, as

"[s]ervices like Snapchat, YouTube or Twitter, but also professional networks like LinkedIn and Xing only offer parts of the services of a social network and are thus not to be included in the relevant market. However, even if these services were included in the relevant market, the Facebook group with its subsidiaries Instagram and WhatsApp would still achieve very high market shares that would very likely be indicative of a monopolization process. ${ }^{\prime 45}$

Therefore, apart from smaller German social networks, Facebook is essentially the only genuine social network, after Google+ has disappeared from the market. Facebook holds market share of more than $90 \%{ }^{46}$ Moreover, the market power of Facebook is supported by the access

41 Bundeskartellamt. (2016) Bundeskartellamt initiates proceeding against Facebook on suspicion of having abused its market power by infringing data protection rules. [press release] 2 March. Available from: https://www.bundeskartellamt.de/SharedDocs/Meldung/EN/Press emitteilungen/2016/02_03_2016_Facebook.html [Accessed 9 March 2019].

42 Bundeskartellamt. (2019) Bundeskartellamt prohibits Facebook from combining user data from different sources. Background information on the Bundeskartellamt's Facebook proceeding. [press release] 2 March. Available from: https://www.bundeskartellamt.de/SharedDocs/ Publikation/EN/Pressemitteilungen/2019/07_02_2019_Facebook_FAQs.pdf_blob= publicationFile\&v=5 [Accessed 9 March 2019]].

43 Ibid.

44 It flows from the Background information on the Bundeskartellamt's Facebook proceeding that Bundeskartellamt conducted a substantial qualitative analysis, as it compared the type of service Facebook provides with other, similar, yet not identical services, such as YouTube.

45 Bundeskartellamt. (2019) Op. cit.

${ }^{46}$ Bundeskartellamt. (2019) Op. cit. 
to competitive relevant data or network effects. ${ }^{47}$ The latter leads to high barriers to entry. Although virtually everyone can enter the market by creating their own social network, such new network will be of little use as far as there is not enough people to network together. The dominant position of Facebook was not threatened by possibility to simultaneous use of several different social networks (multi-homing), which was not proved according to the Bundeskartellamt. ${ }^{48}$

After establishment of the dominant position on the relevant market, Bundeskartellamt focused on the abusive practice Facebook committed. Facebook's lucrative advertising model relies on data collected not only on Facebook, but also by the use of third-party websites and apps via Facebook's embedded tools. ${ }^{49}$ Such off-Facebook data collection ${ }^{50}$ is usually not predicted by Facebook users. ${ }^{51}$ As off-Facebook data are combined with on-Facebook data, they may be used for creating very extended profiles of users. It is true that users technically agree with such conditions, however, as there is no other option for them but to agree on terms set by Facebook (if they want to use Facebook at all), such consent cannot be considered as deliberately given. Taken together with Facebook market power, users have little to no choice. Pursuant to Bundeskartellamt, such practice is also a violation of personal data regulation and right to informational self-determination. ${ }^{52}$

In order to remedy this situation, the German competition authority did not impose any fine on Facebook. Rather, it said that its goal was to change the future behavior of Facebook to the benefit of both competitors and consumers. Bundeskartellamt considered the case to be too complex and

47 Haucap, J. and Heimeshoff, U. (2013) Google, Facebook, Amazon, eBay: Is the internet driving competition or market monopolization? DICE Discussion Paper, (83) p. 3. [online] Available from: http://hdl.handle.net/10419/68229 [Accessed 9 March 2019]; Tucker, C. and Marthews, A. (2012) Social Networks, Advertising, and Antitrust. George Mason Law Review, 19 (5), p. 1217 et seq.

48 Bundeskartellamt. (2019) Op. cit.

49 Ibid.

50 A similar situation was dealt by the CJEU: Judgment of 29 July 2019, Fashion ID GmbH \& Co.KG v Verbraucherzentrale NRW eV, C-40/17, ECLI:EU:C:2019:629.

51 Botta, M. and Wiedemann, K. (2018) EU Competition Law Enforcement vis-à-vis Exploitative Conducts in the Data Economy Exploring the Terra Incognita. Max Planck Institute for Innovation and Competition Research Paper, 18-08, p. 64. [online] Available from: https://ssrn.com/abstract=3184119 [Accessed 4 March 2019].

52 From the competition law perspective, the theory of harm for consumers was based on Facebook users' loss of control over how their personal data are used. Bundeskartellamt. (2019) Op. cit. 
difficult from legal and economic perspective, therefore, at this stage, fine as an additional measure was not imposed..$^{53}$

\subsection{HAS AN EFFECTIVE REGULATORY MECHANISM BEEN ESTABLISHED?}

The German Facebook case is fresh. As Facebook indicated its intention to appeal against the decision ${ }^{54}$, we cannot be sure whether the decision will be overruled or not. Nonetheless, if we assumed that the Bundeskartellamt decision was upheld, would it mean that we have an effective mechanism for regulation of the SMPs? We remain skeptical as to the effects of such decision.

First, one should not overlook the particularities of German competition law. Even though national competition laws of the Member States converge to competition law of the EU, they are not the same. Particularly, since prosecution of abuse of dominant position is prosecution of a unilateral conduct, national competition law can go further than European competition law..$^{55}$ The German legislator detailed the methods of assessing market power in such manner that access to data should be taken into consideration. Therefore, the German legislation is better suited for putting together an infringement of personal data regulation with a breach of competition regulation than the EU legislation.

Second, apart from the wording of legal rules, it is vital to bear in mind that supra-competition interpretation of competition rules is on different level in Germany. It is explicitly recognized by Bundeskartellamt that the highest German court has ruled that constitutional or other legal principles may be considered in abuse of dominant position cases. ${ }^{56}$ When we zoom in on case law of the EU institutions, it is apparent that they have been rather reluctant to broaden competition law analysis by personal data considerations. ${ }^{57}$

53 Ibid.

54 Dreyfuss, E. (2019) German Regulators Just Outlawed Facebook's Whole Ad Business. Wired, 7 February. [online] Available from: https://www.wired.com/story/germanyfacebook-antitrust-ruling/ [Accessed 16 February 2019].

55 See Article 3 para 2 of Council Regulation (EC) No 1/2003 of 16 December 2002 on the implementation of the rules on competition laid down in Articles 81 and 82 of the Treaty.

56 Bundeskartellamt. (2019) Op. cit.

57 Judgment of 23 November 2006, Asnef-Equifax, Servicios de Información sobre Solvencia y Crédito, SL v Asociación de Usuarios de Servicios Bancarios (Ausbanc), C-235/05, ECLI:EU:C: 2006:734, para 63. 
Third, even if infringement of data regulation could support competition law case in a similar manner as in Germany, it is doubtful whether competition law may be considered as the effective regulation for SMPs. For instance, GDPR does not have to be violated in each case. If Facebook users gave effective consent to harvesting off-Facebook data, would it mean that there was no infringement of competition law? If so, this does not reflect the so-called privacy paradox, i.e. the fact that people care about their privacy, but do not act accordingly. ${ }^{58}$ Due to very strong network effects, there are no real alternatives to specific platforms for a huge majority of users; the network effects imply high costs of opt-outs, which makes them impractical. ${ }^{59}$ Furthermore, there is no product and service life-cycle or amortization, as the platform services are continuous with ongoing upgrades (SaaS). There are also very high entry barriers for any would-be competitors. Finally, the competitive advantage makes it easier for these resource-rich platforms to acquire competition or merge their products or features into their own products and services. ${ }^{60}$ Therefore, if Facebook collects off-Facebook data based on a genuine consent only, it may easily happen that users will give their consent and that Facebook will have access to similar amount of data it has nowadays.

Fourth, Bundeskartellamt's decision is related to a highly specific situation. After Facebook put its data processing practices in line with German law, there will be no more ground for holding Facebook conducts accountable. However, as it was described in the first part of this article, issues related to Facebook are far more reaching.

Fifth, competition law is definitely not an effective regulatory mechanism when it comes to the speed of its procedure. Due to the plethora of economic and legal issues which need to be solved before a decision is issued, the investigation often takes months, even years. ${ }^{61}$ In the meantime, damage caused to users or even to civil society may be significant and unrepairable. $^{62}$

58 Op. cit., p. 26.

59 Farrell, J. and Klemperer, P. (2006) Coordination and Lock-In: Competition with Switching Costs and Network Effects. SSRN Electronic Journal. [online] doi: 10.2139/ssrn.917785 [Accessed 15 March 2019].

60 For example, see the Facebook's acquisition of Instagram or WhatsApp.

61 Let us remind that the investigation of Facebook in Germany started in March 2016 with decision rendered in February 2019.

62 Let us assume that elections are at least partially influenced by Facebook. Therefore, if off-Facebook data collection and creation of users' profiles influenced elections, competition law would come too late to remedy the course of election. 
Sixth, what should be the proper remedy once infringement of competition law is recognized? In the German Facebook case, behavioral remedies were imposed by Bundeskartellamt. ${ }^{63}$ However, is such remedy genuinely effective? Who would be able to review whether off-Facebook data collection was truly stopped and that there was no technical or legal loop-hole which would allow its continuing? Last but not least, it seems that competition law is somehow forced to serve purposes it was not originally designed for. Although primary objectives of the competition law vary among states, ${ }^{64}$ it is overall related to the protection of competition to the benefit of consumers. The position of SMPs, as well as all data giants, goes further than to potential deformation of (economic) competition.

\section{CONCLUSION AND DISCUSSION}

While platforms prefer to be understood as technology companies, rather than media companies, thus limiting their responsibility over users' content and behavior, they certainly mediate messages and information and clearly hold some responsibility for the intermediation channels they operate. Accountability in private or market sphere is often understood on a transactional basis; one could simply switch the service if one is not satisfied with the quality of product or service, the price or their ratio. ${ }^{65} \mathrm{But}$ the problem with accountability of SMPs does not lie in poor quality product or service, but rather in (i) negative externalities on communities, such as through election influencing, or facilitation of fake news proliferation, i.e. the service design problem; and (ii) the fact that users may not realize they may be paying too huge a price for the service, in provided personal data or attention, i.e. the price problem, as highlighted also by the recent German Facebook case.

${ }^{63}$ To the notion of behavioural remedies, see, for instance: Kalesná, K. and Patakyová, M. T. (2018) Behavioral vs. Structural Remedies in European and Slovak Competition Law. In: Humberto Ribeiro, Dora Naletina and Ana Lorga da Silva (eds.). Economic and Social Development: 35th International Scientific Conference on Economic and Social Development"Sustainability from an Economic and Social Perspective", Lisbon, Portugal, 15-16 November. Croatia: Varazdin Development and Entrepreneurship Agency, pp. 518-526.

${ }^{64}$ Blažo, O. (2017) Účel zákona o ochrane hospodárskej sútaže ako právno-ekonomické interpretačné pravidlo. In: Mária Patakyová (ed.). Efektívnost' právnej úpravy ochrany hospodárskej sútaže - návrhy de lege ferenda. Bratislava, Slovakia, 25 September. Bratislava: Univerzita Komenského v Bratislave, Právnická fakulta, pp. 5-11.

65 Bovens, M., Schillemans, T. and Goodin, R. E. (2014) Public Accountability. In: Mark Bovens, Robert E. Goodin and Thomas Schillemans (eds.). The Oxford Handbook of Public Accountability. Online edition. Oxford University Press. 
Public accountability thus becomes more relevant and we argue that currently there is a lack of accountability of SMPs. Public accountability implies proper checks and balances and democratic control of power. ${ }^{66}$ Accountability requires answerability (holding one to account), subjection to accountability, agent and principal and the right to require information or justification and a right to sanction if the principal fails. ${ }^{67}$ In terms of the first identified problem, i.e. the service design problem, only very limited public accountability may be exerted on platforms, although recent public hearing of Facebook's CEO and main shareholder Mark Zuckerberg by US Congress shows the validity and necessity of such actions. ${ }^{68}$ A regulatory regime needs to take into account all of the elements of accountability, not merely an ad hoc public inquiry by the legislative branch. As for the second problem, we see how limited the competition authorities can be in addressing the issue fully and in relation to the first issue.

Arguably, in case of SMPs the accountability regimes are not properly set as there is not a clear legal cause of holding platforms accountable for providing infrastructure (inadvertently) tailored to abusive behavior. In this regard, we analyzed the SMPs' self-regulatory efforts and three external regulatory regimes: data protection, consumer protection and competition law. Remedying through data protection and competition law, although the most promising, does not fulfil the requirements for effective and proper regulation of SMPs. This was proved by the German Facebook case. The key problem with the regulation of SMPs appears to lie in the fact that none of the regulatory regimes is able to change the SMP's design. The platforms' design is a crucial determinant of the options or rights users are granted, channels they use to disseminate various information, or what content is permitted or curated by the platforms. ${ }^{69}$ In this sense, the code is the platforms' law, as Lessig put it. ${ }^{70}$ Although certain platforms claim

${ }^{66}$ Han, Y. and Demircioglu, M. A. (2016) Accountability, Politics, and Power. Global Encyclopedia of Public Administration, Public Policy, and Governance, pp. 1-8. [online] doi: 10.1007/978-3-319-31816-5_2453-1 [Accessed 15 March 2019].

67 Murphy, P. et al. (2019) Public service accountability: rekindling a debate. Cham, Switzerland: Palgrave Macmillan, p. 7.

68 At the same time, it showed how limited such action was; many of the inquirers from among representatives possessed limited knowledge of how the platform actually operated or even the gravity of the situation.

69 Lazer, D. (2015) The rise of the social algorithm. Science, 348 (6239), pp. 1090-1091. [online] doi: 10.1126/science.aab1422 [Accessed 15 March 2019].

70 Lessig, L. (2006) Code and other laws of cyberspace: version 2.0. New York: Basic Books. 
to seek also complementary objectives ("Building a global community" Facebook $)^{71}$, the platforms' design is fundamentally driven by the market-oriented ambitions. Yet, if we recognize the importance of SMPs in contemporary society ${ }^{72}$, we may reach a conclusion that platforms' design not only makes the processes more difficult, it may in fact contradict them.

As Lazer et al. proposed, we need to ask how we can build a news ecosystem and culture that value and promote truth. ${ }^{73}$ In doing so we need to review platforms' inner regulations, i.e. the code, algorithms, information filters $^{74}$ and other in-built design features that regulate how information flows in the platform cyberspace. It is necessary to independently review biases of algorithms ${ }^{75}$, consistency of the content regulation in individual cases, but also improve the information asymmetries the users face and safeguard the integrity of political competition. The oversight needs to be publicly appointed, independent on the platform and accountable to the formal democratic structures. ${ }^{76}$ Such actions are warranted by the sheer importance of the platforms for our democracies.

\section{LIST OF REFERENCES}

[1] Act on Unfair Conditions in Commercial Relations with Food as the Object: Zákon o neprimeraných podmienkach v obchodných vztahoch, ktorých predmetom sú potraviny 2013. SI 2012/369. Slovak Republic. In Slovak.

[2] Allcott, H. and Gentzkow, M. (2017) Social Media and Fake News in the 2016 Election. Journal of Economic Perspectives, 31 (2). [online] doi: 10.1257/jep.31.2.211 [Accessed 15 March 2019].

[3] Bartlett, J. (2018) Big data is watching you - and it wants your vote. The Spectator, 24 March. [online] Available from: https:/www.spectator.co.uk/2018/03/big-data-is-

71 Zuckerberg, M. (2018) Building Global Community. [press release] 16 February. Available from: https://www.facebook.com/notes/mark-zuckerberg/building-global-community/10154 544292806634 [Accessed 15 March 2019].

72 The platforms continue to grow in numbers of their users and they are also increasingly more important for socialization, as a news source, for political deliberation and communication and general marketing: Hitlin, P. and Rainie, L. (2019) Facebook Algorithms and Personal Data. Pew Research Center: Internet, Science \& Tech, 16 January. [online] Available from: http://www.pewinternet.org/2019/01/16/facebook-algorithms-and-personal-data/ [Accessed 15 March 2019].

73 Lazer, D. et al. (2018) The science of fake news. Science, 359 (6380), pp. 1094-1096. [online] doi: 10.1126/science.aao2998 [Accessed 15 March 2019].

74 Ibid.

75 Ibid.

${ }^{76}$ Needless to say, this will be difficult to achieve as most SMPs are global phenomena with dispersed country/region-specific regulators. 
watching-you-and-it-wants-your-vote/ [Accessed 15 March 2019].

[4] Blažo, O. (2017) Účel zákona o ochrane hospodárskej sútaže ako právno-ekonomické interpretačné pravidlo. In: Mária Patakyová (ed.). Efektívnost’ právnej úpravy ochrany hospodárskej súṫaže - návrhy de lege ferenda. Bratislava, Slovakia, 25 September. Bratislava: Univerzita Komenského v Bratislave, Právnická fakulta.

[5] Botta, M. and Wiedemann, K. (2018) EU Competition Law Enforcement vis-à-vis Exploitative Conducts in the Data Economy Exploring the Terra Incognita. Max Planck Institute for Innovation and Competition Research Paper. 18-08. [online] Available from: https://ssrn.com/abstract=3184119 [Accessed 4 March 2019].

[6] Bovens, M., Schillemans, T. and Goodin, R. E. (2014) Public Accountability. In: Mark Bovens, Robert E. Goodin and Thomas Schillemans (eds.). The Oxford Handbook of Public Accountability. Online edition. Oxford University Press.

[7] Brian C. Davison v. Loudon County Board of Supervisors et al. (2017) 1:16cv932 (JCC/IDD).

[8] Bundeskartellamt. (2016) Bundeskartellamt initiates proceeding against Facebook on suspicion of having abused its market power by infringing data protection rules. [press release] 2 March. Available from: https://www.bundeskartellamt.de/SharedDocs/Meldung/EN/Presse mitteilungen/2016/02_03_2016_Facebook.html [Accessed 9 March 2019].

[9] Bundeskartellamt. (2019) Bundeskartellamt prohibits Facebook from combining user data from different sources. Background information on the Bundeskartellamt's Facebook proceeding. [press release] 2 March. Available from: https://www.bundeskartellamt.de/SharedDocs/ Publikation/EN/Pressemitteilungen/2019/07_02_2019_Facebook_FAQs.pdf?_blob= publicationFile\&v=5 [Accessed 9 March 2019].

[10] Calvert, C. (2018) Federal judge rules Trump's Twitter account is a public forum. The Conversation, 24 May. [online] Available from: http://theconversation.com/federaljudge-rules-trumps-twitter-account-is-a-public-forum-97159 [Accessed 15 March 2019].

[11] Ceron, A. (2018) Social Media and Political Accountability Bridging the Gap between Citizens and Politicians. Cham, Switzerland: Palgrave Macmillan.

[12] Civil Code: Občiansky zákonník 2019. SI 1964/40. Slovak Republic. In Slovak.

[13] Colangelo, G. and Maggiolino, M. (2018) Data Accumulation and the Privacy-Antitrust Interface: Insights from the Facebook Case for the EU and the U.S. SSRN Electronic Journal. [online] doi: 10.2139/ssrn.3125490. Available from: https://ssrn.com/abstract=3125 490 [Accessed 2 March 2019].

[14] Commercial Code: Obchodný zákonník 2019. SI 1991/513. Slovak Republic. In Slovak

[15] Council Regulation (EC) No 1/2003 of 16 December 2002 on the implementation 
of the rules on competition laid down in Articles 81 and 82 of the Treaty.

[16] Cox, J. (2018) Facebook Is Testing a Feature to Tell You If That DM Came from Russia. VICE, 10 July. [online] Available from: https://motherboard.vice.com/en_us/article/ne5w gw/facebook-testing-feature-direct-message-from-russia? [Accessed 15 March 2019].

[17] Davilla, M. (2017) Is Big Data a Different Kind of Animal? The Treatment of Big Data Under the EU Competition Rules. Journal of European Competition Law \& Practice, 8 (6). [online] doi: 10.1093/jeclap/lpx039 [Accessed 15 March 2019].

[18] Directive 2011/83/EU of the European Parliament and of the Council of 25 October 2011 on consumer rights, amending Council Directive 93/13/EEC and Directive 1999/44/EC of the European Parliament and of the Council and repealing Council Directive 85/577/EEC and Directive 97/7/EC of the European Parliament and of the Council. Official Journal of the European Union (2011/L-304/64) 22 November.

[19] Dreyfuss, E. (2019) German Regulators Just Outlawed Facebook's Whole Ad Business. Wired, 7 February. [online] Available from: https://www.wired.com/story/germanyfacebook-antitrust-ruling/ [Accessed 16 February 2019].

[20] Facebook Newsroom. (2018) How Are We Doing at Enforcing Our Community Standards? [press release] 15 November. Available from: http://newsroom.fb.com/news/2018/11/ enforcing-our-community-standards-2/ [Accessed 15 March 2019].

[21] Facebook Newsroom (2018) Fighting Election Interference in Real Time. [press release] 18 October. Available from: https://newsroom.fb.com/news/2018/10/war-room/ [Accessed 15 March 2019].

[22] Farrell, H. J. and Schneier, B. (2018) Common-Knowledge Attacks on Democracy. SSRN Electronic Journal. [online] doi: 10.2139/ssrn.3273111 [Accessed 15 March 2019].

[23] Farrell, J. and Klemperer, P. (2006) Coordination and Lock-In: Competition with Switching Costs and Network Effects. SSRN Electronic Journal. [online] doi: 10.2139/ssrn. 917785 [Accessed 15 March 2019].

[24] Ferrara, E. (2017) Disinformation and social bot operations in the run up to the 2017 French presidential election. First Monday, 22 (8). [online] doi: 10.5210/fm.v22i8.8005 [Accessed 15 March 2019].

[25] Goel, V. et al. (2018) How WhatsApp Leads Mobs to Murder in India. The New York Times, 18 July. [online] Available from: http://www.nytimes.com/interactive/2018/07/18/ technology/whatsapp-india-killings.html [Accessed March 15 2019].

[26] Guess, A., Nagler, J. and Tucker, J. (2019) Less than you think: Prevalence and predictors of fake news dissemination on Facebook. Science Advances, 5 (1). [online] doi: 10.1126/ 
sciadv.aau4586 [Accessed 15 March 2019].

[27] Han, Y. and Demircioglu, M. A. (2016) Accountability, Politics, and Power. Global Encyclopedia of Public Administration, Public Policy, and Governance. [online] doi: 10.1007/ 978-3-319-31816-5_2453-1 [Accessed 15 March 2019].

[28] Hansen, I. and Lim, D. J. (2018) Doxing democracy: influencing elections via cyber voter interference. Contemporary Politics, 25 (2). [online] doi: 10.1080/13569775.2018.1493629 [Accessed 15 March 2019].

[29] Haucap, J. and Heimeshoff, U. (2013) Google, Facebook, Amazon, eBay: Is the internet driving competition or market monopolization? DICE Discussion Paper, (83). [online] Available from: http://hdl.handle.net/10419/68229 [Accessed 9 March 2019].

[30] Hintze, M. (2018) Viewing the GDPR through a De-Identification Lens: A Tool for Compliance, Clarification, and Consistency. International Data Protection Law, 8 (1).

[31] Hitlin, P. and Rainie, L. (2019) Facebook Algorithms and Personal Data. Pew Research Center: Internet, Science $\mathcal{E}$ Tech, 16 January. [online] Available from: http://www.pewinternet.org/ 2019/01/16/facebook-algorithms-and-personal-data/ [Accessed 15 March 2019].

[32] Isaak, J. and Hanna, M. J. (2018) User Data Privacy: Facebook, Cambridge Analytica, and Privacy Protection. Computer, 51 (8). [online] doi: 10.1109/mc.2018.3191268 [Accessed 15 March 2019].

[33] Jeweler, M. G. (2008) The Communications Decency Act of 1996: Why $\S 230$ is Outdated and Publisher Liability for Defamation Should be Reinstated Against Internet Service Providers. Pittsburgh Journal of Technology Law and Policy, 8. [online] doi: 10.5195/tlp.2008. 40 [Accessed 15 March 2019].

[34] Jones, A. and Sufrin, B. (2016) EU Competition Law. Text, Cases and Materials. 6th ed. Oxford: Oxford University Press.

[35] Judgment of 23 November 2006, Asnef-Equifax, Servicios de Información sobre Solvencia y Crédito, SL v Asociación de Usuarios de Servicios Bancarios (Ausbanc), C-235/05, ECLI:EU:C: 2006:734.

[36] Judgment of 29 July 2019, Fashion ID GmbH \& Co.KG v Verbraucherzentrale NRW eV, C-40/17, ECLI:EU:C:2019:629.

[37] Kalesná, K. and Patakyová, M. T. (2018) Behavioral vs. Structural Remedies in European and Slovak Competition Law. In: Humberto Ribeiro, Dora Naletina and Ana Lorga da Silva (eds.). Economic and Social Development: 35th International Scientific Conference on Economic and Social Development - "Sustainability from an Economic and Social Perspective", Lisbon, Portugal, 15-16 November. Croatia: Varazdin Development and 
Entrepreneurship Agency.

[38] Kerber, W. (2016) Digital Markets, Data, and Privacy: Competition Law, Consumer Law, and Data Protection. SSRN Electronic Journal. [online] doi: 10.2139/ssrn.2770479

[Accessed 15 March 2019].

[39] Langhanke, C. and Schmidt-Kessel, M. (2015) Consumer Data as Consideration. Journal of European Consumer and Market Law, 4 (6).

[40] Lazer, D. (2015) The rise of the social algorithm. Science, 348 (6239). [online] doi: 10.1126/ science.aab1422 [Accessed 15 March 2019].

[41] Lazer, D. et al. (2018) The science of fake news. Science, 359 (6380). [online] doi: 10.1126/ science.aao2998 [Accessed 15 March 2019].

[42] Lessig, L. (2006) Code and other laws of cyberspace: version 2.0. New York: Basic Books.

[43] Müller, K. and Schwarz, C. (2017) Fanning the Flames of Hate: Social Media and Hate Crime. SSRN Electronic Journal. [online] doi: 10.2139/ssrn.3082972 [Accessed 15 March 2019].

[44] Murphy, P. et al. (2019) Public service accountability: rekindling a debate. Cham, Switzerland: Palgrave Macmillan.

[45] Newman, J. M. (2015) Antitrust in Zero-Price Markets: Foundations. University of Pennsylvania Law Review, 164 (1).

[46] Newton, C. (2019) The secret lives of Facebook moderators in America. The Verge, 25 February. [online] Available from: https://www.theverge.com/2019/2/25/18229714/ cognizant-facebook-content-moderator-interviews-trauma-working-conditions-arizona [Accessed 15 March 2019].

[47] Patakyová, M. and Mazúr, J. (2018) Facebook - Global Issue without (Existing) Solution? In: Tomas Kliestik (ed.). Globalization and Its Socio-Economic Consequences 18th International Scientific Conference, Proceedings, (Part V.- Digital Single Market). Rajecké Teplice, 10-11 October. Žilina: University of Žilina.

[48] Patakyová, M. T. (2018) How to Assess the Exploitative Practices of Collecting Societies? European Competition and Regulatory Law Review, 1 (4). [online] doi: 10.21552/core/2017/4/6 [Accessed 15 March 2019].

[49] Regulation (EU) 2016/679 of the European Parliament and of the Council of 27 April 2016 on the protection of natural persons with regard to the processing of personal data and on the free movement of such data, and repealing Directive 95/46/EC (General Data Protection Regulation). Official Journal of the European Union (2016/L-119/1) 4 May.

[50] Silverman, C. (2017) Facebook Is Getting Rid Of Its Fact-Checking Label And Replacing It With This. BuzzFeed News, 20 December. [online] Available from: https://www.buzzfeed 
news.com/article/craigsilverman/facebook-is-getting-rid-of-its-fact-checking-label-and\#. vq128VVB1 [Accessed 15 March 2019].

[51] Stewart, E. (2018) Zuckerberg and Facebook are in trouble. Here's what the government might do about it. Vox, 10 April. [online] Available from: https://www.vox.com/policyand-politics/2018/4/10/17208322/facebook-mark-zuckerberg-congress-testimonyregulation [Accessed 15 March 2019].

[52] Stucke, M. E. and Alan, G. P. (2016) Big Data and Competition Policy. 1st ed. Oxford: Oxford University Press.

[53] Senate Judiciary Committee. (2017) Extremist content and Russian disinformation online: Working with tech to find solutions. [online] Available from: www.judiciary.senate.gov/ meetings/extremist-content-and-russian-disinformation-online-working-with-tech-tofind-solutions [Accessed 15 March 2019].

[54] Tucker, C. and Marthews, A. (2012) Social Networks, Advertising, and Antitrust. George Mason Law Review, 19 (5).

[55] Tufekci, Z. (2018) How social media took us from Tahrir Square to Donald Trump. MIT Technology Review. [online] Available from: http://www.technologyreview.com/s/611806/ how-social-media-took-us-from-tahrir-square-to-donald-trump/ [Accessed 15 March 2019].

[56] Wagner, K. (2018) WhatsApp will drastically limit forwarding to stop the spread fake news, following violence in India and Myanmar. Recode, 19 July. [online] Available from: https:/www.recode.net/2018/7/19/17594156/whatsapp-limit-forwarding-fake-newsviolence-india-myanmar [Accessed 15 March 2019].

[57] Whish, R. and Bailey, D. (2012) Competition Law. 7th ed. Oxford University Press.

[58] Zuckerberg, M. (2018) A Blueprint for Content Governance and Enforcement. [press release] 15 November. [online] Available from: https://www.facebook.com/notes/markzuckerberg/a-blueprint-for-content-governance-and-enforcement/10156443129621634/ [Accessed 15 March 2019].

[59] Zuckerberg, M. (2018) Building Global Community. [press release] 16 February. Available from: https://www.facebook.com/notes/mark-zuckerberg/building-global-community/10 154544292806634 [Accessed 15 March 2019].

[60] Zuckerberg, M. (2018) Note. [press release] 6 April. Available from: https://www.facebook.com/zuck/posts/10104784125525891 [Accessed 15 March 2019]. 